\title{
Succeeding in Scientific Farming
}

\author{
A Survey of the Opportunities Awaiting the Man Who Is Going Back to the Land
}

\author{
By Raymond Francis Yates
}

S CIENCE has invaded every realm of human endeavor and farming has been no exception. Science is showing the way to better, bigger crops, healthier stock and greater efficiency in farm management. The "rule-of-thumb" farmer is gradually becoming educated although he may not appreciate the fact. The gospel of scientific farming, through the good work of our Department of Agriculture, is fast spreading and the farm is becoming more and more like an industry.

The reader can feel that he is indebted to Dr. H. C. Taylor, Chief of the Office of Farm Management, De partment of Agriculture, for the information imparted in this article. There is probably no man in the United States better qualified to give advice on this subject than Dr. Taylor, who, before coming to the Department of Agriculture, was head of the Department of Agricultural Economics at the University of Wisconsin. The author has taken the liberty directly to quote Dr. Taylor in many instances. As the subject is such a difficult one to treat in the allowable space, the author felt that any original views he had on the subject would have to be subordinated to those of a man who knew a great deal more about the field.

When Dr. Taylor was asked what education he considered necessary to succeed in scientific farming he answered that, "a so-called 'higher' academic education is desirable but not essential. 'There are great numbers of farmers who conduct their farms on a scientific basis, but who have not had the advantage of more than a common school education. On the other hand, there are those who have completed courses in agricultural colleges but have not been able to make a success of farming. In general it may be said that education neither creates nor destroys a good farmer. The tendency is for education to improve both tendency is for education to improve both
classes. The essential thing is that the classes. The essential thing is that the
farmer understand the forces with which he has to deal and possess the wisdom to adjust his actions to his conditions. Other things being equal, the college man will not only do better in this regard, but make a more helpful citizen."

The mention of education suggests the question of whether or not a man can succeed in scientific farming without attending college. Anyone contemplating entering this field who cannot see the way clear to attending school may be encouraged by the fact that only a small percentage of the successful farmers in this country are college trained. It is a mooted question whether or not these men

would have been more successful had they possessed the advantage of a thorough college training. It is possible that the greater part of them would have at tained more success if they had a thorough training such as. that offered by a few of the leading colleges of this country today.

Statistics show that the percentage of college trained farmers is rapidly increasing. There is probably greater opportunity for success for the self-trained
man in this field than in any other. Any wideman in this field than in any other. Any wideawake, alert young man with plenty of ambition
and with a yearning for the invigorating outdoor life of and with a yearning for the invigorating outdoor life of
the farm can succeed without attending college. The the farm can succeed without attending college. The garnering of the necessary knowledge for success canwithout practical experience.

Farming is one thing that cannot be successfully taught by a correspondence school course or any amount of reading without the advantage of practical experience. The young man desiring to succeed in this field should first get on a farm, whether it is his this field should first get on a farm, whether it is his own or not, and then study should be started. In fol-
lowing out a course of this kind one should rememiber lowing out a course of this kind one should remember that the Department of Agriculture can be depended upon for information along most any line of farming. This department is devoted to research work of this country.

The demand for men trained in scientific agriculture is increasing every year. This demand is by no means confined to the operation of farms. It come from State and Federal departments, agricultural col-
leges and universities, as well as from commercial

firms that have to do with farm products. When he was asked what he believed to be the necessary qualifications for a young man entering the field of scientific farming, Dr. Taylor answered: "The ing. It is desirable, although perhaps not altogether necessary, that one who goes into farming should have been reared upon a farm or at least should have spent coen reared upon a farm or at least should have spent tions are, reasonably good health, business ability which involves sound judgment, a realization of one's limitation and the love for country life. In general it may be said that the successful operation of a farm requires all those qualifications which make for a successful career in any other business or profession, with the one exception-that farming requires a closer application of those qualifications and gives greater freedom of action."

To one about to enter the scientific agricultural field the question of the length of time needed for training is an important one. Dr. Taylor answers it in this way: "As I have attempted to explain, a man may be a scientific farmer without having gained a knowledge of his scientific methods through academic training. On the whole, however, the academic method is the quicker way of gaining this scientific knowledge. A four-year course at a good agricultural college is desirable. If it is not possible to obtain this, a twoyear course may answer the purpose, although it will not take the place of the longer period of training where the work involved is highly technical. It is often necessary for the one intending to take up a highly technical line of work to spend from one to three

ECAUSE of the present slackening up in industrial activities throughout this land of ours, it is altogether natural that we should have a powerful revival of the back-to-the-land movement. or it is a fact that this movement comes and goes just like the tides of the ocean; in boom times, when the factories and mills and business rom the countryside to the cities. But with the advent of slack times and the laying off of factory and mill and business workers, there is a gradual counter-flow or back-to-the-land movement. "So it is a most survey of the opportunities in scientific farming. Mr. Yates tells us many interesting things about present-day farming, and we certainly elieve he has made out a strong case for the man who is going back the land.-THE EDITOR.

wants to run his farm." Of course, with salaries there must be considered the question of living expenses said that there are few high salaried positions to be had in this field. On the other hand there is no definite limit to the amount that may be earned by a man in business for himself. This will be determined by the amount of land he has available and the nature of -his rops.

There is always need for specialists in every branch of scientific farming. A man may specialize in the raising and care of various kinds of stock, or he may ecialize in wheat, corn or fruit.

Dr. Taylor was asked what he thought of the college courses being offered in scientific farming. He said that he did not believe they were perfect any more than he believed that the college courses in any given field were perfect. The courses are better now than they have
been in the past and they seem to be continually improving.

What should the ambition of every scientific farmer be? Dr. Taylor answered this inspiringly when he said: "To obtain a greater grasp and a more complete his own environment in such a manner as will make farming more profitable, and to become a leader in the tablishing of better living conditions in the country." Any farmer who uses the forces at his commandland, labor, capital and managerial ability-with a moderate degree of efficiency, is a benefactor to mankind. A scientific farmer is only scientific to the degree in which he makes efficient use of the above orces. This being the case, it would necessarily follow that a scientific farmer is a greater benefactor to mankind than is the farmer who does not employ scientific methods.

The following information taken from a bulletin issued by the U. S. Department of Agriculture will be of interest to those who are contemplating a farming career. Agriculture is the greatest single line of industry in the nation. Since 1916. the value of its annual output has exceeded $\$ 20,000,000,000$ while in 1919 the estimated value of crops, and of live stock and animal products totaled nearly $\$ 25,000,000,000$, which is about the equivalent of our entire national debt. These figures, of course, do not represent net value, because much of the crop production is fed and marketed in the form of live stock, nor do they represent the net return of profit to the farmers, but return of profit to the farm
merely the gross farm output.

years in a graduate school."

The chap who cannot attend college should just keep on "plugging" until he feels that he has succeeded.
Ability varies so in different individuals, as well as the capacity for learning, that it would be difficult to say just how long it would take a inan to become a sucwould also depend upon whether he had had previous experience in farming. A man who had been brought up on a farm would have a tremendous advantage over a man brought up in the city although the city man does not present a hopeless case by any means. Do a great number of scientific farmers go into business for themselves? Dr. Taylor's answer to this important question follows: "Yes; although the demand for those trained in scientific agriculture by State and Federal institutions, agricultural colleges and universities, has been so great that the farm has not taken as many of these men as it is likely to take in the future. It is to be expected that as the agricultural colleges turn out more graduates, a greater percentage of them will return directly to the farm. On the other hand, it must be explained that one of the reasons why graduates of agricultural colleges turn to salaried positions, rather than going to the farm, is the engage in farming."

It is difficult to say just what the salary of a thoroughly experienced man in scientific agriculture can be It is one of those questions that can be answered largely by "it all depends." In scientific farming it is "determined by the amount some millionaire, farming by proxy, is willing to pay in order to get just the man he
The value of farm buildings and equipment was reported in the 1910 census as $\$ 40,991,000,000$. With the rise in value since the last census, and on basis of present prices, the value of farm property is now probably in excess of $\$ 80,000,000,000$, five times the value of all the railroads in 1910 , nearly 20 times the value of the iron and steel industry, nearly 40 times the value of the textile industry, and forty times the combined value of more than 75 distinct groups of miscellaneous industries Except for the railroads the value of live stock alone on farms on January 1 , 1920 , was several times greater than the capital valuation of any other single industry in the United States. The 1.910 census also shows that approximutely $12,300,00$ persons-the farmer himself and his hired help-were then employed in agriculture, 20 per cent more than in all manufacturing and mechanical industries combined; 372 per cent more than in transportation, 242 per cent imore than all the bankers, merchants, wholesalers, jobbers and retailers ; and 1:281 per cent more than the number engaged in the extraction of minerals. It is estimated that at the present time there are approximately 7,000,000 farmers in the United States and that the number of adult male farmers and hired farm helpers is probably about $14,000,000$. More people are engaged in farming, and are directly or indirectly dependent upon farming for a. living than any other single industry in the country.

These facts emphasize the fundamental importance of agriculture. Unless agriculture prospers, other industries cannot hope to prosper-and agriculture cannot prosper unless the individual farm business is profitable. 